\title{
Quantifying the Value of U.S. Tariff Preferences for Developing Countries*
}

\author{
Judith M. Dean ${ }^{\dagger}$ \\ John Wainio ${ }^{\ddagger}$
}

\begin{abstract}
In recent debates, trade preference erosion has been viewed by some as damaging to developing countries, and by others as insignificant, except in a few cases. However, little data have been available to back either view. The objective of this paper is to improve our measures of the size, utilization and value of all US non-reciprocal trade preference programs, in order to shed some light on this debate. Highly disaggregated data are used to quantify the margins, coverage, utilization and value of nonagricultural and agricultural tariff preferences, for all beneficiary countries in the US regional programs and in the GSP. Results show that US regional tariff preference programs are generally characterized by high coverage of beneficiary countries' exports, high utilization by beneficiary countries, and low tariff preference margins (except on apparel). For 29 countries, the value of US tariff preferences was $5 \%$ or more of 2003 dutiable exports to the US, even after incorporating actual utilization. Most of this value is attributable to non-agricultural tariff preferences, and to apparel preferences in particular. These results suggest that preference erosion may be significant for more countries than many had thought.
\end{abstract}

JEL: $\quad$ F13

Keywords: trade preference erosion, development, utilization

World Bank Policy Research Working Paper 3977, August 2006

The Policy Research Working Paper Series disseminates the findings of work in progress to encourage the exchange of ideas about development issues. An objective of the series is to get the findings out quickly, even if the presentations are less than fully polished. The papers carry the names of the authors and should be cited accordingly. The findings, interpretations, and conclusions expressed in this paper are entirely those of the authors. They do not necessarily represent the view of the World Bank, its Executive Directors, or the countries they represent. Policy Research Working Papers are available online at http://econ.worldbank.org.

\footnotetext{
* Revised version of paper presented at the "Preference Erosion: Impacts and Policy Responses," International Symposium, WTO, Geneva, June 13-14, 2005. We are grateful to Maya Shivakumar and Nick Grossman for their superb work assembling and analyzing data. We also thank Pat Thomas for her valuable help constructing tables and Peg MacKnight for her help with the USITC Dataweb. The views expressed here do not necessarily reflect the views of the USITC, or any of its individual Commissioners, or the USDA.

${ }^{\dagger}$ U.S. International Trade Commission.

${ }^{\ddagger}$ U.S. Department of Agriculture.
} 


\section{Introduction}

There has been much debate over the value of industrial countries' preferential trade programs which grant duty-free or reduced duty access to many developing countries’ exports. In 2005 non-agricultural market access discussions at the WTO, Oxfam International argued that preference erosion "is a serious loss for these countries, and one for which they should be compensated. ${ }^{1 \text { ” }}$ The Prime Minister of Mauritius, speaking to the G-90 Ministers' Meeting in July 2004, stated that it is "crucial that modalities be developed to protect the preferential as well as favorable conditions of access of these countries. Otherwise, they run the risk of being chased out of the market with devastating socio-economic consequences... 2» In contrast, the IMF Managing Director told the WTO General Council in October, 2004, that according to an IMF study, "vulnerability to preference erosion is heavily concentrated in a sub-set of products, especially sugar and bananas,” and thus, "assistance to help countries cope with preference erosion can and should be closely targeted at the countries at risk. ${ }^{3{ }^{\prime}}$

Ostensibly, a country granted trade preferences would see demand for its exports grow, relative to other exporting countries still facing MFN tariffs. If the country receiving preferences is small, its exports would continue being sold in the importing country at the prevailing tariff-inclusive price, with the exporter earning the difference. Thus, the benefits of such preferences for the exporting country would be increased exports and a transfer of rent from the importing country. But how important are these trade preferences to developing countries? Are the tariff margins large? Do countries fully utilize

\footnotetext{
${ }^{1}$ Oxfam International - Oxfam International contribution regarding NAMA Negotiations 25-29 April 2005 World Trade Organisation, Geneva. http://www.oxfam.org.uk/what_we_do/issues/trade/sub_nama.htm, downloaded July 12, 2005.

${ }^{2}$ Speech of the Prime Minister, Hon. P. R. Bérenger, Republic of Mauritius, at the opening of the G-90 Ministers' Meeting 12 July 2004 http://ncb.intnet.mu/mfa/speech/sppm.htm, downloaded July 12, 2005.
} 
their preferential access? Is all rent actually earned by the exporting countries? If so, how large is this rent in relation to a country's overall exports? If it is significant, do trade preferences granted to one developing country come at the expense of another (Panagariya, 2004)?

Only recently have studies attempted to provide quantitative answers to some of these questions. Alexandraki and Lankes (2004) calculate the product level tariff margins granted by the US, EU, Canada and Japan, and then use these to derive an aggregate value of preferences for each beneficiary country. They find 18 countries for which the value of preferences exceeds $5 \%$ of the value of their exports. Their results suggest that the problem is heavily concentrated in mostly small island economies dependent upon sugar and bananas, and to a lesser extent upon textiles. However, as the authors note, these values could be overstated, since they assume full utilization of preferences, constant world prices, and full rent transfer to the beneficiary countries.

Brenton and Ikezuki (2004) provide an assessment of the scope and value of US preferences under the African Growth and Opportunity Act (AGOA) for 2002. They argue that overall, least developed AGOA beneficiary countries (LDCs) saw little expansion in the list of products eligible for duty-free access under AGOA, since they already had such access under GSP. Thus, the countries likely to benefit more from AGOA would be the non-LDCs. However, eligibility for apparel preferences significantly affects AGOA utilization rates. Among countries with such status, the LDCs have the least restrictive rules of origin, and are therefore likely to gain more than the non-LDCs. Brenton and Ikezuki's data show wide variation in utilization, AGOA tariff preferences averaging about $6 \%$, and only 6 AGOA countries with values of preferences (AGOA plus GSP) exceeding $5 \%$ of their total exports to the US.

\footnotetext{
${ }^{3}$ Statement by the IMF Managing Director, Rodrigo de Rato, Managing Director of the IMF, to the WTO General Council 22 October 2004 http://www.wto.org/english/news_e/news04_e/gc_stat_imf_22oct04_e.htm, downloaded July 12, 2005.
} 
The objective of this paper is to improve our measures of the size, utilization and value of all US non-reciprocal trade preference programs, in order to shed some light on this debate. Highly disaggregated data are used to quantify tariff preference margins, coverage, and utilization for nonagricultural and agricultural tariff preferences, for all beneficiary countries in the US regional preference programs and in the GSP. The overall value of preferences is estimated assuming full utilization of preferences, and then re-estimated to incorporate actual utilization. Values for non-agricultural and agricultural preferences are also estimated.

Results show that US regional preference programs are generally characterized by high coverage of beneficiary countries' exports, high utilization by beneficiary countries, and low tariff preference margins (except on apparel). The GSP has relatively poorer coverage in general, and low preference margins. GSP is used very little as an alternative to the regional programs, but is highly utilized by countries with no alternatives. After incorporating actual utilization, we find that 29 beneficiary countries had US tariff preferences valued at 5\% or more of dutiable exports to the US, and 17 countries had values exceeding $5 \%$ of total exports to the US in 2003. For 9 of these countries, US preferences were valued at $15 \%$ or more of dutiable exports. Most of this value was attributable to non-agricultural tariff preferences, and in particular, apparel. The remaining value was small, and was attributable largely to jewelry, chemicals, electrical machinery, petroleum-related products, melons, fresh cut flowers, frozen orange juice, raw cane sugar, and fresh asparagus. The removal of apparel quantity restrictions in 2005 is likely to have reduced the value of US apparel preferences since 2003. While further analysis is needed, these results suggest that US preference erosion may be significant for more countries than previously thought.

\section{Overview of US Non-Reciprocal Trade Programs in 2003}

In 2003, 143 countries and territories were eligible for tariff preferences under the Generalized System of Preferences (GSP). GSP treatment in the US is duty-free and covers "most dutiable manufactures and 
semi-manufactures and selected agricultural, fishery, and primary industrial products not otherwise dutyfree” (USTR, 1999). In 1996, nearly 2000 additional items were designated duty-free for LDCs. ${ }^{4}$ However, relative to other US preferential programs, GSP has the lowest product coverage. Items deemed import-sensitive products are excluded from program coverage by law. Agricultural products subject to a tariff-rate quota (TRQ) are not eligible for duty-free access on any quantities in excess of the quota. Other ineligible products include most textiles, apparel, watches, footwear, handbags, luggage, work gloves, and other apparel made partially or wholly from leather (US Government, 2004). GSP has additional limitations, including: periodic expiration; loss of GSP eligibility due to automatic graduation once the World Bank’s high income country category is reached; loss of GSP eligibility on a product once “competitive needs limits” (CNL) have been exceeded. ${ }^{5}$

The African Growth and Opportunity Act (AGOA) granted duty-free status to more than 6,400 products imported from Sub-Saharan African (SSA) countries, as part of the Trade Act of 2000 (USITC 2004b). In 2003, 38 countries were eligible for preferences under the AGOA program (www.agoa.gov). AGOA extended GSP duty-free status to a larger set of goods than covered by the GSP. For non-LDC beneficiaries, products are either eligible for preferences under AGOA or under GSP, but not under both. However, for LDC beneficiaries, some products are eligible for both programs. AGOA exempts beneficiary countries from the CNL. The program also grants duty-free and quota-free access to apparel made in eligible sub-Saharan African countries from US fabric, yarn and thread. Apparel imports made with regional fabrics were subject to a cap, with built-in growth over a period of 8 years. In addition, the Special Rule for Apparel (SRA) allowed LDCs to receive duty-free access for apparel made with fabrics

\footnotetext{
${ }^{4}$ In 2003, 41 countries were eligible for expanded benefits under the US GSP/LDC program.

${ }^{5} \mathrm{CNL}$ are ceilings set for each product and country, and are intended to prevent the extension of preferential treatment to countries that are considered competitive in the production of an item. With certain qualifications, a country automatically loses its eligibility for a given product the year following that in which the ceiling is passed.
} 
originating from third countries until September 2004. ${ }^{6}$ AGOA II (part of the Trade Act of 2002) expanded preferential access, and increased the cap for apparel made with regional fabric. AGOA III (2004) extended the program until 2015, and the third country fabric provision until 2007.

The Caribbean Basin Economic Recovery Act (CBERA) is an extension of the Caribbean Basin Initiative, begun in 1984 (USITC, 2003). This program eliminated or reduced tariffs on eligible products imported from designated Caribbean and Central American countries and territories. The Caribbean Basin Trade Partnership Act (CBTPA) is the most recent extension of CBERA, and was implemented as part of the Trade Act of 2000. In 2003, 24 countries were eligible for CBERA benefits and, of those, 14 countries eligible for CBTPA. Under CBTPA, a number of import-sensitive products became eligible for preferential duty treatment, including apparel, petroleum and petroleum products. CBTPA authorizes unlimited duty-free entry for imports of apparel assembled in CBERA countries from fabrics made and cut in the United States of US yarns. If the cutting takes place in CBTPA countries rather than the US, the apparel must be sewn together with US thread. ${ }^{7}$ CBTPA also provides for some preferential access for apparel made from regional fabric, however unlike AGOA, it has no third country fabric provision.

The Andean Trade Preference Act (ATPA) granted duty-free access to many imports from Bolivia, Columbia, Ecuador and Peru, beginning in 1991 (USITC, 2004a). After expiring in December 2001, ATPA was renewed retroactively as the Andean Trade Promotion and Drug Eradication Act (ATPDEA) in late 2002. ATPA $^{8}$ has broader product coverage than the GSP, and eligibility is not constrained by the GSP CNL or by the possibility of graduation. In 2002, ATPA preferential treatment was expanded to include previously excluded import sensitive products such as petroleum and petroleum derivatives, apparel and textiles, footwear and tuna in foil packages. ATPA allows unlimited duty-free

\footnotetext{
${ }^{6}$ Although Botswana and Namibia are not LDCs, they were given third country fabric provision eligibility in 2003.

${ }^{7}$ For additional eligibility criteria, see USITC (2005), page 1-10.
} 
and quota-free treatment for imports of textiles and apparel articles made in ATPA countries, using yarn or fabric or fabric components wholly formed in the US. Similar to the CBTPA, ATPA also provides some preferential access for apparel made from regional fabric, but no third country fabric provision.

\section{Data Description}

A preference database was constructed for this study using trade and tariff data at the US HTS 8digit level, extracted from the USITC DATAWEB database (http://dataweb.usitc.gov) and the USITC Tariff Database (http://www.usitc.gov/tata/hts/other/dataweb). All US imports in HS chapters 1 through 97 in the year 2003 are included. ${ }^{9}$ The USITC records US imports from beneficiary countries by customs value $^{10}$ in current US dollars. The import data include the preferences claimed, the value of total imports, dutiable imports (ex post), the duties paid, the quantity imported, and preference eligibility status by country and program. The use of preferences is indicated by the preference claimed when the product entered the United States. ${ }^{11}$

MFN and preferential tariffs, including both ad valorem and specific tariffs are converted to ad valorem equivalents (AVEs), using the USITC method. ${ }^{12}$ While the ITC tariff database does include AVEs of tariff-rate quotas, it does not include any AVE estimates of import quotas or other types of

\footnotetext{
${ }^{8}$ Hereafter, ATPA refers to ATPA or ATPADEA.

${ }^{9}$ Note that chapters HS61 and HS62 do include the value of apparel entering the US under the production-sharing program (HTS 9802.00.80), though that value is not broken out separately.

${ }^{10}$ Customs value is equivalent to f.o.b. value.

${ }^{11}$ There are cases where the claim is later denied, but these represent a tiny proportion of cases.

${ }^{12}$ US AVE tariffs for HTS 8-digit items with specific or compound rates are estimated by the following steps. 1) Where there is US MFN import trade for an HTS item, the AVE is estimated by duties divided by dutiable US imports. Trade entering under special tariff preference programs is not included. 2) Where there is no US MFN import trade for an item, the quantity and customs value of all US imports under that item are used and the MFN specific and compound rates are applied to calculate the tariffs that "would have been collected " if the trade had entered as MFN trade rather than under a special program. The duties thus calculated are divided by the customs value to estimate the AVE. 3) Where there is no US import trade at all for an item in a given year, the quantity and customs value of imports (MFN if available, all trade if not) in that item from the previous full year are used and the MFN specific and compound rates for the current year are used to calculate the tariffs that "would have been collected " if the trade had entered as MFN trade in the current year. The duties thus calculated are divided by the
} 
quantitative restrictions (QRs). The implications of omitting the 2003 US QRs on apparel products are discussed below. The tariff data include detailed information on preference eligibility by product and program.

\section{US Tariff Preferences on Non-Agricultural Products ${ }^{13}$}

Figure 1 shows US imports of non-agricultural products in 2003 from beneficiary countries by tariff treatment. The CBERA countries are split into those eligible for CBTPA and those eligible for CBERAonly, since the CBTPA includes apparel preferences and has broader non-apparel coverage. Countries which are exclusively eligible for the GSP are split into two groups: GSP-only and GSP-LDC.

The first striking feature of figure 1 is the high overall use of the regional preference programs. In 2003, the US imported about $\$ 19.6$ billion of non-agricultural products from CBTPA countries, 50\% of which was apparel. Nearly half of these imports entered the US under the CBTPA program. Similarly, of the $\$ 9.8$ billion the US imported from ATPA countries (11\% of which was apparel), nearly $60 \%$ entered under the ATPA program. AGOA countries accounted for \$19.1 billion of US non-agricultural imports, $8 \%$ of which was apparel. About $68 \%$ of these imports entered the US under the AGOA preference program. Only the CBERA-only beneficiaries made little use of regional preferences. Of the \$1.8 billion US non-agricultural imports from these countries, only 7\% entered under CBERA.

The second striking feature of figure 1 is the low use of GSP. Only $1 \%$ of US imports from CBPTA countries and from CBERA-only countries came in under the alternative GSP program. US imports from ATPA and AGOA beneficiaries under GSP were only 3\% and 4\%, respectively. Even the non-LDCs who are beneficiaries of GSP alone made little use of the program. Only 15\% of the $\$ 113.8$ billion of non-agricultural imports from the GSP non-LDC beneficiaries entered the US under GSP. In

Customs value to estimate the AVE. 4) If there is no US import trade for the given year or the previous year, the Office of Tariff Affairs and Trade Agreements of the USITC is asked to provide an estimated AVE. 
contrast, more than half of the $\$ 8.8$ billion non-agricultural imports from GSP-LDCs did enter the US under the GSP program. Though apparel represented 13\% of US imports from GSP-LDC countries, most of this was excluded from the GSP, leaving only $1 \%$ of apparel imports entering under the program. Are US non-agricultural preferences comprehensive?

Whether or not countries underutilize US preferences may depend, in part, on how extensive those preferences are. We measure the scope of preferences by calculating coverage rates, which are defined as the ratio of eligible US imports to total dutiable US imports, where dutiable is defined as subject to duty if no preference program is claimed. Apparel coverage is problematic, since technically no apparel product is eligible, ex ante, for preferential tariff treatment. The regional programs all have product eligibility requirements - typically, rules of origin (RoOs) regarding the components of the garments—which may or may not be met. The AGOA program also requires country apparel eligibility, and grants nearly all AGOA-LDCs SRA eligibility. In this study, overall coverage rates for countries in these programs are calculated assuming that all apparel imports from eligible countries are "potentially eligible” for duty-free access. This yields apparel coverage rates of 100 percent. $^{14}$ In the case of CBERA-only and the GSP, apparel coverage rates are calculated based on actual product eligibility.

Table 1 shows coverage rates for all non-agricultural imports and for non-apparel and apparel imports separately. Data for regional programs are shown on the left, and for the alternative GSP program on the right. Nearly 100 percent of US non-agricultural imports from members of CBTPA and ATPA were eligible for preferences under these regional programs. With the exception of El Salvador, coverage rates for non-apparel imports were $90 \%$ or more under both these programs. For CBERA-only countries, the scope of regional preferences was more diverse. Six of the ten members had CBERA

\footnotetext{
${ }^{13}$ Non-agricultural products are defined as all those not specified in Annex 1of the WTO Agreement on Agriculture. Detailed data are available from the authors upon request. All values are based on imports in HS chapters 1-97.
} 
coverage rates of $90 \%$ or more, but the remaining four had rates well below $50 \%$. Under the alternative GSP program, coverage of non-apparel imports exceeded 90\% in seven of the CBTPA and ATPA countries, but overall GSP coverage rates were well below 50\% for most beneficiaries. For CBERA-only countries, GSP coverage was similar to the regional program coverage.

For non-LDCs, there is no overlap between the AGOA program coverage and GSP coverage. Adding up coverage under both programs reveals that virtually 100 percent of US non-agricultural imports from all AGOA non-LDCs (except Eritrea) were eligible for preferences in 2003. The same was true for non-apparel imports (with the exception of Botswana and Swaziland). Coverage rates were more diverse among the LDCs. Nine out of the 21 AGOA LDC beneficiaries had AGOA coverage of $90 \%$ or more, while for 9 others, AGOA coverage was negligible. For most other LDCs, low (high) AGOA coverage corresponded to high (low) GSP coverage. Thus, 14 LDCs had complete coverage and another 4 LDCs had 50\%-90\% coverage under the combined preference programs. AGOA coverage of nonapparel imports was generally very low compared to GSP, with the exception of petroleum-related products. Eight of the countries with complete AGOA coverage had exports to the US comprised almost totally of petroleum-related products. ${ }^{15}$

Preference coverage was much lower, on average, and more varied for GSP-only countries (table 2). The mean coverage rate for the 60 non-LDCs was only $44 \%$, and nearly half the countries had less than $30 \%$ of their dutiable exports covered by GSP. Of the 15 GSP-LDCs, half had coverage rates of $90 \%$ or more, while the other half had coverage rates near or below $25 \%$. For countries such as Bangladesh, Pakistan, Nepal, Sri Lanka, and Cambodia, whose exports to the US are dominated by apparel, GSP coverage rates were extremely low.

\footnotetext{
${ }^{14}$ The alternate extreme would be to assume that the apparel trade which qualified for preferences in 2003 is the maximum that could have qualified in that year. This would imply that utilization rates were always 100 percent. ${ }^{15}$ Cameroon, Chad, Congo (ROC), Congo (DROC), Cote d'Ivoire, Gabon, Nigeria, and Seychelles.
} 
Are US non-agricultural preferences fully utilized?

Utilization is defined as the share of eligible imports entering the US under the preference program. From table 1 it is immediately evident that utilization rates are typically below $100 \%$. Some of the evidence suggests that utilization rates may be correlated with coverage rates. The ATPA and CBTPA members with virtually 100\% coverage of their exports under the regional programs, had high average utilization rates: $83 \%$ and $63 \%$, respectively. Both non-apparel and apparel utilization were similarly high, though CBTPA countries showed more diverse utilization than ATPA countries. The CBERA-only countries' utilization rates tended to be lower, on average, as were their coverage rates. One might think that some of the underutilization by CBTPA, CBERA or ATPA beneficiaries could be explained by the use of the GSP program instead. However, table 1 also shows that these countries made very little use of GSP preferences. ${ }^{16}$ In fact, almost no non-agricultural imports which were eligible for both ATPA, CBERA, or CBTPA preferences and for GSP preferences entered the US under the GSP. Among AGOA non-LDCs, high combined AGOA and GSP coverage corresponded to high combined utilization. With the exception of Eritrea, Gabon, and Mauritius, each country showed combined utilization rates of $75 \%$ or more. Average utilization of non-apparel preferences was only $50 \%$, though seven countries had rates exceeding 75\%. For LDCs, AGOA preference coverage was less generous than GSP coverage. Overall, average utilization for each program was about 50\%. High (low) AGOA coverage tended to correspond to high (low) AGOA utilization. However, if AGOA utilization was low, GSP utilization tended to be high. Thus, average utilization of the combined preference programs was above 50\%. Interestingly, the eight AGOA countries exporting exclusively petroleumrelated products showed wide variation in utilization, despite complete AGOA coverage.

Eleven of the 20 AGOA apparel-eligible countries made very high use of apparel preferences,

\footnotetext{
${ }^{16}$ Columbia and Ecuador have higher GSP utilization but very low GSP coverage.
} 
while five others did not use them at all. Since the AGOA exporters with high apparel utilization all had SRA eligibility, we might suspect that high utilization was driven by the ability to avoid costly RoOs. However, of the nine AGOA apparel-eligible countries with low apparel utilization, five had SRA eligibility, and two became eligible late in the year (Mali and Niger). Thus, more analysis is needed to ascertain the role of the SRA in preference usage.

For countries benefiting exclusively from GSP, utilization appears to be quite high, despite the relatively low coverage of GSP preferences (table 2). For both non-LDCs and LDCs, average utilization was $60 \%$. About half of the non-LDCs and half of the LDCs had utilization rates exceeding $75 \%$. Particularly noteworthy are the beneficiaries whose exports include a large share of apparel. While GSP coverage rates for Pakistan and Sri Lanka were only 7\% and 5\%, respectively, their utilization rates were $80 \%$ and $90 \%$. Similarly for Bangladesh and Nepal, GSP coverage was only 2\% and 5\%, respectively, but utilization rates were $89 \%$ and $76 \%$. This suggests that countries without the alternative of a regional preference program do make very high use of the GSP, but are constrained by that program's limited coverage.

\section{Are US non-agricultural preference margins large?}

High utilization of preferences has occurred despite evidence that preference margins are generally low. The tariff preference margin is calculated as the difference between the nominal MFN ad valorem tariff equivalent (AVE) and the nominal preferential AVE, at the HS 8 digit level. Unweighted averages for each country and program are shown in table 1. Across member countries and all eligible US non-agricultural imports, AGOA preference margins were the highest on average (14\%) in 2003. CBTPA preference margins ranked second with a mean of 9\%, and ATPA preference margins third with a mean of $8 \%$. In all three of these programs, the range of margins was wide--from less than $1 \%$ to $59 \%$. In contrast, CBERA-only, GSP-only, and GSP-LDC programs had very low average nominal preferences of $4 \%, 4 \%$ and $5 \%$ respectively, and much less dispersion. The range of preference margins under 
CBERA-only was very narrow-from less than $1 \%$ to $10 \%$. For GSP-only and GSP-LDC-only countries, preference margins ranged from less than $1 \%$ to $26 \%$ and to $30 \%$, respectively.

Separating non-apparel from apparel margins (table 1) reveals a very different picture. Nonapparel preference margins average 3\% to 5\% for ATPA, CBTPA and CBERA countries, and show little variation across countries within each program. AGOA non-apparel preference margins are much higher--5\% to $10 \%$ for more than half the countries, and 10\%-20\% for a few (such as Cape Verde, Kenya, Senegal, and Sierra Leone). A major exception to this was petroleum. Despite its importance in USAGOA trade, average petroleum preference margins by country did not exceed 2\%, and most were well below $1 \%$.

Apparel preference margins stand in sharp contrast to the non-apparel margins. Again assuming that all apparel exports from eligible countries are "potentially eligible” for US tariff preferences, apparel average margins under AGOA, CBTPA and ATPA are two or three times as high as those for non-apparel for nearly all member countries. AGOA apparel margins show wide variation, from a high of $22.3 \%$ for Uganda to a low of $6.7 \%$ for Niger.

\section{US Tariff Preferences on Agricultural Imports ${ }^{17}$}

Figure 2 shows US agricultural imports in 2003 from beneficiary countries by tariff treatment. About \$3.9 billion of US agricultural imports in 2003 entered duty-free under non-reciprocal trade preference programs. The largest portion of this preferential trade-about $40 \%$ or $\$ 1.5$ billion--came in under the GSP program. Only a small portion of that amount, about \$20.4 million, came in under the GSP-LDC program. The CBERA program accounted for 37 percent (\$1.4 billion) of preferential imports, followed by the ATPA program under which $\$ 784$ million was imported. Still relatively new in 2003, the AGOA program accounted for the remainder, valued at $\$ 122$ million. 
The regional preference programs are particularly important for countries in the Caribbean and Andean regions, with almost 50 percent of US agricultural imports from CBERA countries and 40 percent from ATPA countries entering the US under these programs in 2003. The GSP program has dwindled in importance for these countries, with only 4 percent of CBERA and 5 percent of ATPA agricultural exports to the US coming in under the GSP. When countries in these regions had a choice between using either the regional preference program or the GSP, on average the regional program was used in almost 90 percent of cases. AGOA countries made almost equal use of the two programs, shipping about 11 percent of their agricultural exports to the US under the GSP and 12 percent under AGOA. In contrast, countries that only qualified for the GSP or the GSP-LDC relied much less on preferences in the US market. Less than 17 percent of agricultural exports from the GSP countries came in under preferences, while less than 6 percent of GSP-LDC exports entered under the program. Unlike non-agricultural imports, a large percentage of US agricultural imports from these beneficiary countries already had MFN duty-free status.

Are US agricultural preferences comprehensive?

Program coverage varies widely across programs and countries. Table 3 shows the share of dutiable agricultural trade that was eligible for preferences in 2003. For participants in the CBERA and ATPA programs virtually 100 percent of dutiable exports to the US were covered by regional preferences. None of these countries shipped much to the US that was not either MFN duty-free or eligible for preferences. However, duties on the relatively small subset of products not covered by these programs tended to be prohibitively high, averaging about 43 percent.

For some of these countries, the GSP program alone provided broad coverage for their imports. Over 90 percent of the dutiable agricultural exports from 11 of the 26 CBERA and ATPA beneficiaries

\footnotetext{
${ }^{17}$ Agricultural products are here defined as those specified in Annex 1 of the WTO Agreement on Agriculture.
} 
were eligible for duty free treatment under the GSP, although this program was seldom used. For the others, however, the regional programs expanded the range of products eligible for preferences. In countries such as the Bahamas, Costa Rica, Jamaica, Nicaragua, and the Netherlands Antilles, the CBERA program offered much more preferential coverage than the GSP. Aggregating across beneficiaries within each program, 42 percent of ATPA and 48 percent of CBERA program imports were made up of products not covered under the GSP. Although the remaining product were covered by both the GSP and regional preferences, countries generally chose to utilize the regional program.

AGOA agricultural coverage was generally quite low for both non-LDCs and LDCs. Only Benin had 100\% coverage under AGOA. As noted earlier, AGOA does not extend preferences to tariff lines already covered by the GSP for non-LDC beneficiaries. Thus, the sum of the coverage rates provided by both programs reflects the overall preferential access provided their exports in the US market. When the coverage rates of both programs are taken into account, the range of preferences offered to AGOA nonLDCs approaches $100 \%$. All AGOA LDCs already had 100\% coverage rates under the GSP, with the exception of Tanzania. However, the combined coverage of GSP and AGOA also gave Tanzania complete coverage.

Coverage rates for those countries that only qualified for preferences under the GSP or GSP-LDC programs are found in table 4 . In general, these coverage rates tended to be low, with an average over all 61 countries of only 33.5\%. Countries which were exclusively GSP-LDC eligible had coverage rates double those of GSP-only countries.

Are US agricultural preferences fully utilized?

The availability of preferences does not necessarily mean that all beneficiaries’ products covered by these programs will actually enter duty-free. Complex and costly program regulations can limit a

Detailed data is available from the authors upon request. 
recipient's ability to utilize these preferences. RoOs are most often cited as the primary limiting factor restricting beneficiary countries’ ability to fully utilize tariff preferences (Wainio et al., 2005). Table 3 shows the share of eligible imports that actually received preferences under each program in 2003 (utilization, \%). In the case of agricultural exports from CBERA and ATPA countries, utilization rates were quite high. With the exception of Peru, ATPA utilization rates were $90 \%$ or more. Nine out of 14 CBTPA countries had utilization rates above $90 \%$, while the others' rates were between $70 \%$ and $87 \%$. CBERA-only countries showed more diversity in utilizing CBERA preferences, but rates were still fairly high. Thus, utilization of regional preferences was quite high, though not complete. In contrast, beneficiaries of ATPA, CBERA, and CBTPA alike made little use of the GSP. However, in cases where a regional program was underutilized, the alternative GSP preferences were utilized. Thus, nearly all beneficiaries’ eligible agricultural products entered under one of the preference programs. This is in sharp contrast to non-agricultural products from ATPA, CBERA or CBTPA countries, which generally had both low coverage and low utilization under GSP.

In the case of AGOA countries, however, the results are more mixed. While 14 AGOA countries had overall utilization rates of over 90\%, 2 countries (Benin and Niger) failed to make use of either the AGOA or GSP, even though some of their exports to the US were eligible to receive preferences under these programs. Several others failed to use AGOA while making only limited use of the GSP. Still relatively new in 2003, AGOA was only used in agriculture by 10 of the 38 eligible recipients, while 22 AGOA countries utilized the GSP.

Despite the relatively low coverage rates under GSP, GSP-only countries had high utilization rates (table 4). Utilization averaged 89\%, and nearly three-quarters of the 61 countries that utilized the GSP and GSP-LDC had rates of $80 \%$ or more. Countries that were exclusively GSP-LDC eligible had lower average utilization (60\%), though their coverage rates were much higher than GSP non-LDCs. Are US agricultural preference margins large? 
Agricultural products deemed to be import-sensitive are excluded from preferential access under US programs. These products tend to be those with the highest MFN tariffs, while products accorded preferential access tend to face low MFN rates. Of the 1,432 agricultural tariff-lines which face an MFN rate greater than zero, 1,204 (84\%) are included in at least one of the nonreciprocal trade preference programs. The MFN tariffs levied on these products in 2003 ranged in size from less than $1 \%$ to $79 \%$, with the average equal to $6.4 \%$. About $55 \%$ of the products that are granted some preferential access under these programs face MFN tariffs of 5\% or lower. Many of these tariffs are levied as in-quota rates on products facing TRQs, so they are only granted preferential access on a limited quantity of imports. Clearly, the margin of preference - the extent to which the preferential tariff is below the MFN tariff - on most of these products is somewhat limited.

Tables 3 and 4 show the simple average nominal tariff preference, or margin of preference, that each beneficiary faced on the sub-set of agricultural products it exported to the US under these programs. The averages ranged from $0.1 \%$ in the case of St. Kitts-Nevis' exports under CBERA to $21.9 \%$ for Swaziland's exports under AGOA. The overall average across the 101 countries was about $5.4 \%$, with the average margins of preference under AGOA (9.6 \%) and CBERA (7\%) being the highest. Few countries exported a product-mix which faced an average nominal tariff preference greater than the $6.4 \%$ average tariff across all products eligible for duty-free treatment. One might expect that beneficiaries would tend to export those products facing higher MFN rates, since they would have a greater competitive advantage in these markets over countries facing MFN rates. However, many of the agricultural products that beneficiaries tend to export under these programs, particularly those produced in tropical climates, already face low MFN tariffs in the US.

\section{Quantifying the Value of US Preferences}

As mentioned above, the US tariff preferences should increase exports from the beneficiary country to the US, relative to other countries whose exports face the non-preferential tariff. The preference will also 
imply a rent transfer to the exporter, since the beneficiary's exports will face no (or a reduced) tariff, but will sell at the non-preferential tariff-inclusive price in the US market. The value of the tariff preference would then be composed of: (i) the rent earned on the level of exports prior to the preference; (ii) the rent earned on the additional exports sold as a result of the preferences.

Following Alexandraki and Lankes (2004), we make the following simplifying assumptions:

A.1. Products are perfect substitutes irrespective of their country of origin.

A.2. The exporting country is a price-taker in world markets.

A.3. All rents from preferential access accrue to the exporter.

A.4. A change in the US trade policy regime will not lead to a change in world prices.

We then add the additional assumption that in programs which have apparel preferences, all apparel is potentially eligible for those preferences. Under these assumptions, the duty savings from preference programs can be approximated by the difference between the total duties that would have been collected on existing levels of US imports from a beneficiary country in the absence of any program, and the actual duties collected given the program(s). The value of preferences is then the beneficiary country's duty savings as a share of its dutiable exports to the US. Assuming that preferences are fully utilized, their value can be calculated using equation (1):

$$
\text { Value }_{j}=\sum_{i}\left(t_{i}^{M F N}-t_{i j}^{p}\right)\left(\frac{\text { CustomsValue }_{i j}}{\text { CustomsValue }_{j}}\right) * \text { Eligibility }_{i j}
$$

where:

$i$ is US HTS 8-digit product, $j$ is exporting country $p$ indicates preference program Customs Value is the value of dutiable exports to the US Eligibility $_{i j}=\left\{\begin{array}{l}1 \text { if product is eligible for any US preference } \\ 0 \text { if not }\end{array}\right\}$.

Note that calculating equation (1) will yield an upper bound estimate on value for at least two reasons: imports from beneficiaries would be smaller than existing levels in the absence of preferences; the MFN 
tariff overstates the price increase in the US market due to tariffs, since some US trading partners are part of reciprocal preferential trade agreements (e.g., NAFTA).

Assumptions A.1-A.4 and the assumptions of complete apparel eligibility and full utilization of preferences all suggest that the estimates from (1) would indeed be upper bound estimates. While market power and the degree of rent transfer are difficult to quantify, we have quantified preference utilization, and found it to be less than full, often even at the HTS 8-digit level. In order to incorporate this incomplete utilization, we recalculate the value of preferences using (2):

$$
\text { Value }_{j}=\sum_{i}\left(t_{i}^{M F N}-t_{i j}^{p}\right)\left(\frac{\text { CustomsValue }_{i j}}{\text { CustomsValue }_{j}}\right) * \text { Eligibility }_{i j} * \text { Utility }_{i j}
$$

where Utility ${ }_{i j}$ is the \% of imports (HTS 8-digit level) which entered the US under any preference program.

Table 5 shows the value of all preference programs for all beneficiary countries, and for all LDC beneficiary countries. Below this, the value of preferences is shown for beneficiaries of both regional programs and GSP, and finally beneficiaries of GSP alone. For each of these country groups, the table shows the value of all preferences for all beneficiaries in that group, and for individual countries within that group, with duty savings exceeding $5 \%$ of their total dutiable exports to the US. The first set of columns shows values assuming full utilization (from equation (1)), and decomposes these values into the share due to non-agricultural and agricultural preferences. The second set of columns shows values after incorporating actual utilization (from equation (2)).

Looking at the overall figures, the results in the first set of columns in table 5 suggest that the potential duty savings from all US preference programs represents a very small share of beneficiaries’ dutiable exports to the US. Across beneficiary groups, however, countries in the CBTPA program and those in the AGOA-LDC program show duty savings exceeding $10 \%$ of their dutiable exports to the US. Most of this value is attributable to non-agricultural preferences. The most striking feature of table 5 is 
that 35 countries show values exceeding 5\% of their dutiable exports to the US: 3 CBERA-only, 12 CBTPA, 2 ATPA, 15 AGOA, and 3 GSP countries. Values range from 5.1\% (Mali) to 23\% (Cape Verde), and tend to be highest for members of CBTPA and AGOA. For Haiti, Belize, El Salvador, Honduras, Guatemala, Botswana, Swaziland, Kenya, Mauritius, Cape Verde, Lesotho, Uganda, Madagascar, and Ethiopia, the value of US preferences exceeded 15\% of their dutiable exports to the US in 2003. A second notable feature of table 5 is that a very large proportion of countries in regional programs make the list, while only 3 countries from the GSP-only group make the list. The third interesting feature is that almost universally, the largest proportion of the value of preferences is attributable to non-agricultural preferences.

The second set of columns in table 5 shows that the incorporation of actual utilization significantly changes the assessment of the value of preferences for quite a few countries. The overall values of preferences for countries in the CBTPA program and in the AGOA-LDC program fall, though they remain quite high, at $8.8 \%$ and $13.6 \%$ of dutiable exports, respectively. The number of countries with preferences valued above $5 \%$ of dutiable exports drops to 29 . Nearly all the countries which are members of regional groups remain on the list, but only 1 of the countries which are exclusively GSP eligible remains. There is significant change in the magnitudes of the values, however. The countries for which the value of US preferences exceeds $15 \%$ of dutiable exports now includes only Belize, Botswana, Swaziland, Kenya, Cape Verde, Lesotho, Uganda, Madagascar and Ethiopia. CBTPA beneficiaries show the largest adjustment in value after incorporating utilization, though values for half these countries still exceed $10 \%$. With a few exceptions, AGOA member countries show virtually no change in the value of preferences. Once again, the largest proportion of value for all countries comes from non-agricultural trade preferences.

While the value of preferences may be low for some countries when measured against total dutiable exports, it may represent a very large share of the value of their non-agricultural or agricultural 
exports. Table 6 lists countries for which the value of non-agricultural preferences exceeds $5 \%$ of dutiable non-agricultural exports to the US, after incorporating utilization. This list is nearly the same as the list in table 5. For 17 of these 29 countries values exceeded $10 \%$. With a few exceptions, most of this value is attributable to apparel preferences. Other significant products include petroleum-related products, ${ }^{18}$ chemicals, jewelry, and electrical machinery. Table 7 shows 23 countries for which the value of agricultural preferences exceeded 5\% of dutiable agricultural exports to the US, after incorporating actual utilization. Most of these countries do not appear in table 5. Five of these beneficiaries had values exceeding $10 \%$. Of the total preference value of all agricultural products, $50 \%$ was accounted for by 5 products in 2003: melons, fresh cut flowers, frozen orange juice, raw cane sugar, and fresh asparagus.

There are at least three reasons why apparel accounts for such a large share of the value of preferences for many countries: apparel often accounts for a large share of exports; apparel exporting countries had high apparel utilization rates; apparel exports had relatively high preference margins. However, the removal of QRs on apparel in January 2005 (with the completion of the Agreement on Textiles and Clothing) reduced the relative prices of apparel imports from China (prior to the reimposition of QRs), South Asia, and ASEAN countries, where QRs had been highly restrictive. Thus, US apparel imports from CBTPA, ATPA and AGOA countries were likely to fall relative to their 2003 levels. Even if tariff preference margins in 2005 remained similar to those in 2003, these margins would be applied to a smaller value of apparel imports, thus reducing the value of the preferences below those in tables 5 and 6. Data from the Dept. of Commerce suggest that US 2005 apparel imports from SubSaharan Africa dropped by 3.1\%, from CBI dropped by 0.2\%, and from ATPA actually rose by 35.9\% compared to 2003. ${ }^{19}$ These aggregate figures do not suggest a radical drop in the value of apparel

\footnotetext{
${ }^{18}$ Although the value of preferences for some AGOA countries comes exclusively from petroleum-related exports, none of these countries showed values exceeding $1 \%$ of dutiable exports to the US.

${ }^{19}$ Major Shippers Report, http://www.otexa.ita.doc.gov/msr/cat1.htm, downloaded June 2006.
} 
preferences. However, changes in imports varied greatly within these regions. ${ }^{20}$

The results in table 5 suggest that more countries may be impacted by the removal of US preferences than had been thought previously. To facilitate a comparison, table 5 includes the value of preferences calculated with respect to total exports to the US. Using an approach similar to this study, Brenton and Ikezuki (2004) found 6 AGOA countries for which values exceeded 5\% of total exports to the US in 2002 after incorporating utilization: Madagascar, Mauritius, Malawi, Swaziland, Kenya, and Lesotho. Our results for 2003 include these six (with similar value estimates), and add Cape Verde, Mozambique, and Botswana, with much higher value estimates. We find, as did Brenton and Ikezuki, that most of this value is attributable to preferential access for apparel. Using more aggregated data and assuming full utilization, Alexandraki and Lankes (2004) found 18 countries for which the value of all preferences from the US, EU, Canada and Japan, altogether, exceeded 5\% of total exports. Table 5 shows 19 countries--half of Alexandraki and Lankes' list and 10 additional countries--for which the value of US preferences alone exceeds 5\% of total exports assuming full utilization. After incorporating actual utilization, table 5 shows that 17 countries’ values exceed this threshold.

\section{Concluding Remarks}

Close examination of US import data reveals that countries which were members of ATPA, CBTPA, and CBERA tended to have very high utilization of regional preferences, and lower GSP utilization, though CBERA utilization was on average lower and more diverse than the other regional programs. AGOA non-LDCs, for which regional preference coverage and GSP preference coverage are complementary, had very high combined utilization of AGOA and GSP preferences. In many cases, AGOA non-LDCs fully utilized both preference programs. AGOA LDCs, for which AGOA coverage was less generous than

\footnotetext{
${ }^{20}$ For example, within SSA, apparel imports from Swaziland grew by $14.4 \%$ while imports from Mauritius fell by $38.1 \%$. Within CBI, US apparel imports from Nicaragua grew by $47.9 \%$, while those from the Dominican Republic fell by $12.9 \%$.
} 
GSP (particularly for non-agricultural, non-apparel products), showed somewhat lower combined utilization rates, and made more use of GSP than AGOA. In general, utilization of preferences was strongly related to preference coverage. The GSP program was the exception. Countries which were exclusively members of GSP had very high GSP utilization rates, despite relatively low coverage rates. This was particularly true of beneficiaries with exports dominated by apparel.

While utilization rates are high, average tariff preference margins in the regional preference programs were relatively low for most countries, for non-apparel exports. AGOA countries generally had higher non-agricultural preference margins than other beneficiary countries. For all apparel-eligible countries, preference margins on apparel were about three times higher than other non-agricultural products. For non-agricultural products, these low margins are largely the result of low US MFN tariffs. In contrast, for agricultural products, low preference margins are largely due to the exclusion of products which face high tariffs. Overall, average GSP preference margins are lower than those offered by the regional preference programs, largely due to less extensive product coverage and to the lack of apparel preferences.

While the erosion of US tariff preferences may not have large impacts on development, it may be significant for a larger number of countries and products than many had thought. After incorporating actual utilization, 29 countries had values of US tariff preferences exceeding $5 \%$ of dutiable exports to the US, and 17 countries had values exceeding 5\% of total exports to the US in 2003. For 9 of these countries, US preferences were valued at $15 \%$ or more of their total dutiable exports. The largest proportion of this value was attributable to non-agricultural preferences, particularly preferences on apparel. The 2005 removal of US quantitative restrictions on apparel trade has reduced apparel imports from CBI and for AGOA countries by a small amount, but has actually raised apparel imports from ATPA, and has led to a wide variation of increases and decreases in imports across beneficiary countries. Thus, more work needs to be done to clarify the impact of the completion of the ATC on the value of US 
non-reciprocal preferences.

Several other caveats must be noted. We have assumed that the difference between the MFN tariff and the preferential tariff accurately represents the rent transfer on each dollar of exports from the beneficiary countries. But the existence of NAFTA and other regional agreements would tend to reduce the prevailing tariff-inclusive US price below the MFN tariff-inclusive price, lowering the rent a beneficiary could earn. In addition, to the extent that this rent is actually shared by the exporters, middlemen, and/or the US itself, the value of US preferences for beneficiaries would fall. Finally, this analysis has assumed that world prices are unaffected by the introduction of tariff preferences. Yet some beneficiary countries are large enough to affect the prevailing price in the US market for their products, thus lowering the value of their preferences. These limitations suggest that further research is still needed to assess the importance of preference erosion on beneficiary countries. 


\section{References}

Alexandraki, K. and H. Lankes (2004). “The Impact of Preference Erosion on Middle Income Developing Countries,” IMF Working Paper No. 169.

Brenton, P. and T. Ikezuki (2004). "The Initial and Potential Impact of Preferential Access to the US Market under AGOA,” World Bank Policy Research Working Papers No. 3262.

Panagariya, A. (2002). "EU Preferential Trade Policies and Developing Countries,” World Economy, Vol. 25, No.10, November 2002, pp. 1415-32.

US Government (2004). US Federal Code. Title 19, Chapter 12, Subchapter V, found at: http://www4.law.cornell.edu/uscode/html

USITC (2005), The Impact of the Caribbean Basin Economic Recovery Act(Seventeenth Report 20032004), USITC Publication 3804.

USITC (2004a). The Impact of the Andean Trade Preference Act(Tenth Report 2003) USITC Publication No. 3725.

USITC (2004b). US Trade and Investment with Sub-Saharan Africa (Fifth Annual Report 2004), USITC Publication 3741.

USTR (1999). US Generalized System of Preferences Guidebook, found at: http://www.ustr.gov/assets/Trade_Development/Preference_Programs/

Wainio, J., S. Shapouri, M. Trueblood, and P. Gibson (2005). “Agricultural Trade Preferences and the Developing Countries,” USDA-ERS Economic Research Report Number 6, May 2005, found at: http://www.ers.usda.gov/Publications/ERR6/ 
Figure 1. Share of U.S. Non-Agricultural Imports by Type of Tariff Regime, 2003

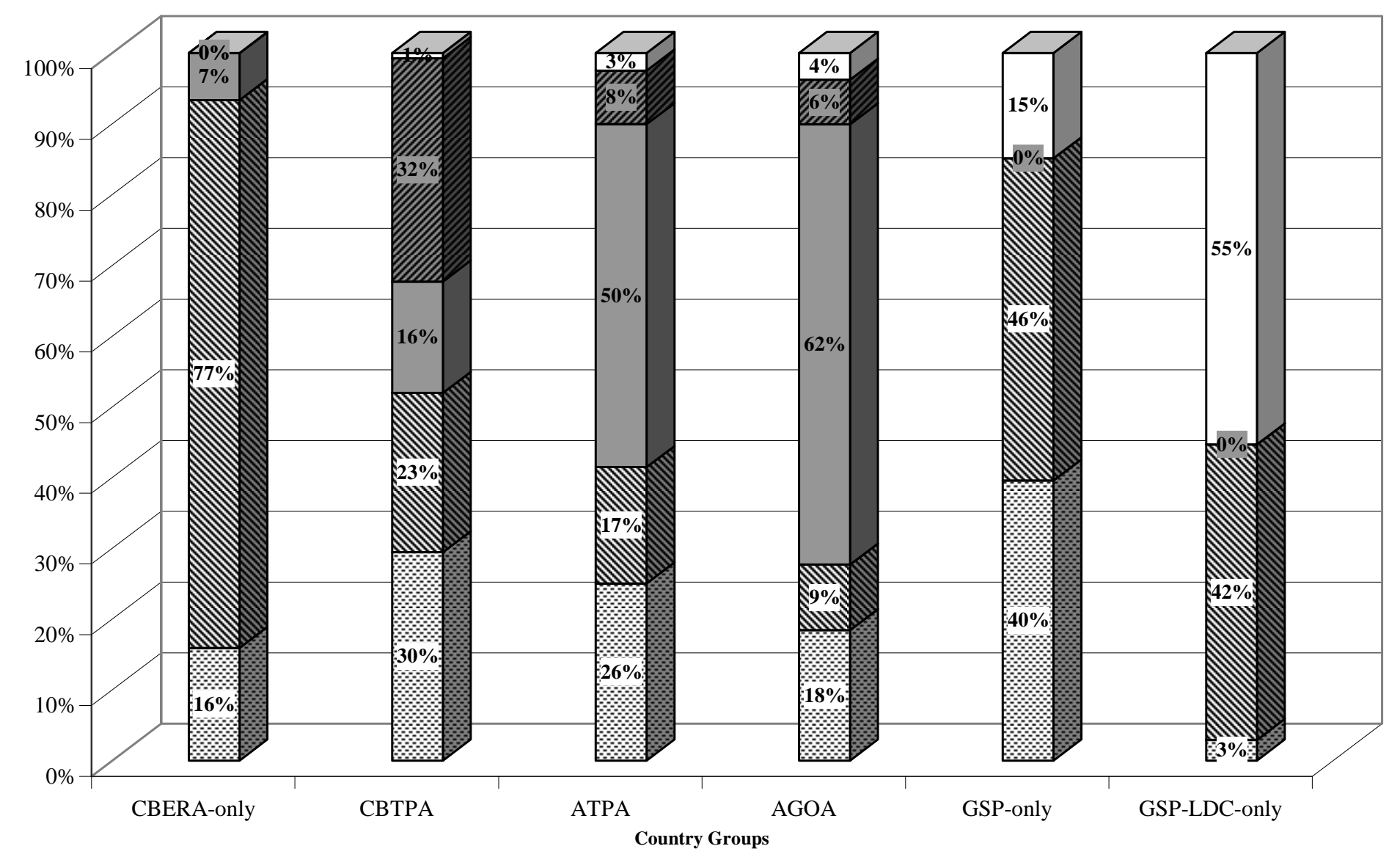

圈 Duty-free $\mathbb{\mathbb { N }}$ MFN $\square$ Regional Pref--Non-Apparel $\quad$ Regional Preference--Apparel $\square$ GSP 
Figure 2: Share of U.S. Agricultural Imports by Type of Tariff Regime, 2003

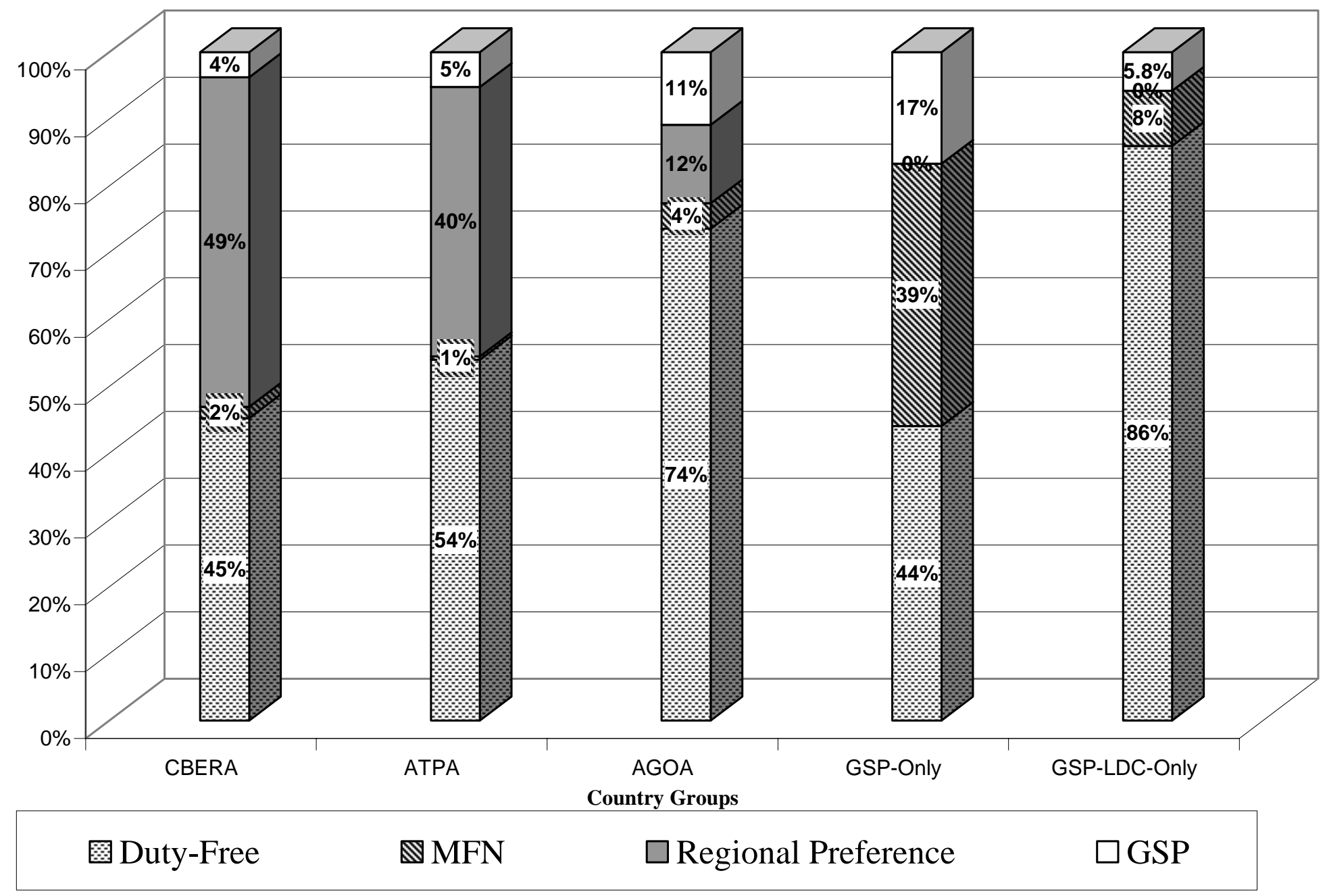


Table 1. US Non-Agricultural Imports: Preference Coverage, ${ }^{1}$ Utilization, ${ }^{2}$ and Average Nominal Tariff Preference, ${ }^{3} 2003$

\begin{tabular}{|c|c|c|c|c|c|c|c|c|c|c|c|c|}
\hline & \multicolumn{2}{|c|}{ CBERA Coverage } & \multicolumn{3}{|c|}{ CBERA Utilization } & \multicolumn{3}{|c|}{ CBERA Av. Tariff Pref. } & \multicolumn{2}{|c|}{ GSP Coverage } & \multirow{2}{*}{$\begin{array}{c}\text { GSP Utilization } \\
\text { Overall } \\
\end{array}$} & \multirow{2}{*}{$\begin{array}{c}\text { GSP Av. Tariff Pref. } \\
\text { Overall } \\
\end{array}$} \\
\hline & Overall & $\begin{array}{l}\text { Non- } \\
\text { App }\end{array}$ & Overall & $\begin{array}{l}\text { Non- } \\
\text { App }\end{array}$ & App & Overall & $\begin{array}{l}\text { Non- } \\
\text { App }\end{array}$ & App & Overall & $\begin{array}{l}\text { Non- } \\
\text { App }\end{array}$ & & \\
\hline Antigua & 98 & 98 & 4 & 4 & & 4.5 & 4.5 & & 27 & 27 & 16 & 3.9 \\
\hline Aruba & (.) & (.) & 49 & 50 & 0 & 3.9 & 3.8 & 4.6 & & & & \\
\hline Bahamas & 29 & 29 & 100 & 100 & 100 & 3.4 & 3.4 & 4.2 & & & & \\
\hline Br Virgin Is & 44 & 42 & 7 & 8 & 0 & 4.3 & 4.1 & 10.0 & 31 & 34 & 0 & 4.0 \\
\hline Dominica Is & 99 & 100 & 98 & 98 & & 3.3 & 3.3 & & 99 & 100 & 0 & 3.3 \\
\hline Grenada Is & 100 & 100 & 20 & 20 & & 3.8 & 3.8 & & 100 & 100 & 0 & 3.8 \\
\hline Montserrat Is & 91 & 95 & 0 & 0 & & 2.1 & 2.1 & & 72 & 75 & 0 & 2.5 \\
\hline Netherlands Ant & 1 & 1 & 40 & 40 & & 3.6 & 3.6 & & & & & \\
\hline St Kitts-Nevis & 98 & 100 & 96 & 96 & & 2.9 & 2.9 & & 93 & 95 & 2 & 3.1 \\
\hline \multirow[t]{3}{*}{ St Vinc / Gren } & 100 & 100 & 100 & 100 & 100 & 4.3 & 4.1 & 4.9 & 100 & 100 & (.) & 4.5 \\
\hline & \multicolumn{2}{|c|}{ CВTPA Coverage } & \multicolumn{3}{|c|}{ CBTPA Utilization } & \multicolumn{3}{|c|}{ CBTPA Av. Tariff Pref. } & \multicolumn{2}{|c|}{ GSP Coverage } & GSP Utilization & GSP Av. Tariff Pref. \\
\hline & Overall $^{4}$ & $\begin{array}{l}\text { Non- } \\
\text { App }\end{array}$ & Overall $^{4}$ & $\begin{array}{l}\text { Non- } \\
\text { App }\end{array}$ & $\mathrm{App}^{4}$ & Overall $^{4}$ & $\begin{array}{l}\text { Non- } \\
\text { App }\end{array}$ & App $^{4}$ & Overall & $\begin{array}{l}\text { Non- } \\
\text { App }\end{array}$ & Overall & Overall \\
\hline Barbados & 100 & 100 & 20 & 20 & 3 & 4.8 & 3.5 & 15.7 & 34 & 35 & 17 & 2.9 \\
\hline Belize & 100 & 100 & 76 & 4 & 86 & 8.8 & 3.2 & 14.2 & 12 & 98 & 13 & 4.2 \\
\hline Costa Rica & 99 & 98 & 73 & 79 & 70 & 7.4 & 4.9 & 16.8 & 32 & 92 & 12 & 3.7 \\
\hline Dominican Rep & 99 & 97 & 76 & 65 & 82 & 8.2 & 4.3 & 15.8 & 30 & 86 & 7 & 3.8 \\
\hline El Salvador & 98 & 60 & 65 & 77 & 64 & 11.2 & 5.0 & 15.4 & 2 & 38 & 32 & 4.0 \\
\hline Guatemala & 99 & 96 & 42 & 94 & 34 & 10.0 & 3.2 & 15.6 & 5 & 34 & 11 & 4.6 \\
\hline Guyana & 96 & 91 & 83 & 81 & 85 & 12.1 & 4.8 & 18.5 & 40 & 91 & 21 & 4.3 \\
\hline Haiti & 100 & 100 & 66 & 34 & 67 & 12.6 & 3.7 & 17.3 & 5 & 97 & 18 & 4.4 \\
\hline Honduras & 100 & 98 & 71 & 20 & 76 & 10.5 & 4.4 & 16.1 & 8 & 96 & 4 & 4.1 \\
\hline Jamaica & 100 & 100 & 86 & 57 & 87 & 9.2 & 5.2 & 17.2 & 3 & 90 & 6 & 3.6 \\
\hline Nicaragua & 100 & 100 & 31 & 32 & 31 & 13.0 & 5.8 & 16.6 & & & & \\
\hline Panama & 99 & 99 & 48 & 51 & 9 & 6.9 & 4.8 & 14.4 & 49 & 53 & 26 & 3.7 \\
\hline St Lucia Is & 100 & 100 & 61 & 89 & 0 & 9.4 & 4.3 & 18.3 & 11 & 16 & 41 & 3.5 \\
\hline Trin \& Tobago & 100 & 100 & 90 & 90 & 11 & 4.3 & 5.0 & 14.4 & 37 & 37 & 0 & 3.5 \\
\hline
\end{tabular}




\begin{tabular}{|c|c|c|c|c|c|c|c|c|c|c|c|c|}
\hline & \multicolumn{2}{|c|}{ ATPA Coverage } & \multicolumn{3}{|c|}{ ATPA Utilization } & \multicolumn{3}{|c|}{ ATPA Av. Tariff Pref. } & \multicolumn{2}{|c|}{ GSP Coverage } & \multirow{2}{*}{$\begin{array}{c}\text { GSP Utilization } \\
\text { Overall } \\
\end{array}$} & \multirow{2}{*}{$\begin{array}{c}\text { GSP Av. Tariff Pref. } \\
\text { Overall }\end{array}$} \\
\hline & Overall $^{4}$ & $\begin{array}{l}\text { Non- } \\
\text { App }\end{array}$ & Overall $^{4}$ & $\begin{array}{l}\text { Non- } \\
\text { App }\end{array}$ & App $^{4}$ & Overall $^{4}$ & $\begin{array}{l}\text { Non- } \\
\text { App }\end{array}$ & App $^{4}$ & Overall & $\begin{array}{l}\text { Non- } \\
\text { App }\end{array}$ & & \\
\hline Bolivia & 100 & 100 & 90 & 89 & 90 & 10.1 & 5.3 & 14.3 & 77 & 98 & 9 & 4.5 \\
\hline Colombia & 99 & 99 & 71 & 74 & 53 & 7.8 & 4.9 & 14.5 & 7 & 8 & 45 & 4.0 \\
\hline Ecuador & 99 & 93 & 85 & 89 & 77 & 8.2 & 4.6 & 15.6 & 7 & 6 & 37 & 4.3 \\
\hline \multirow[t]{3}{*}{ Peru } & 94 & 99 & 89 & 85 & 90 & 8.2 & 4.9 & 14.3 & 52 & 82 & 8 & 4.2 \\
\hline & \multicolumn{2}{|c|}{ AGOA Coverage } & \multicolumn{3}{|c|}{ AGOA Utilization } & \multicolumn{3}{|c|}{ AGOA Av. Tariff Pref. } & \multicolumn{2}{|c|}{ GSP Coverage } & GSP Utilization & GSP Av. Tariff Pref. \\
\hline & Overall $^{4}$ & $\begin{array}{l}\text { Non- } \\
\text { App }\end{array}$ & Overall $^{4}$ & $\begin{array}{l}\text { Non- } \\
\text { App }\end{array}$ & App $^{4}$ & Overall $^{4}$ & $\begin{array}{l}\text { Non- } \\
\text { App }\end{array}$ & $\mathrm{App}^{4}$ & Overall & $\begin{array}{l}\text { Non- } \\
\text { App }\end{array}$ & Overall & Overall \\
\hline Botswana $^{5,6}$ & 99 & 0 & 89 & & 89 & 17.6 & & 17.6 & 1 & 49 & 0 & 2.5 \\
\hline Cameroon ${ }^{5,6}$ & 99 & 99 & 100 & 100 & 0 & 9.7 & 9.6 & 9.9 & 1 & 1 & 16 & 4.0 \\
\hline Congo (ROC) & 100 & 100 & 90 & 90 & & 3.8 & 3.8 & & (.) & (.) & 64 & 4.8 \\
\hline Cote d'Ivoire ${ }^{5,6}$ & 97 & 98 & 80 & 80 & 0 & 7.7 & 5.7 & 9.4 & 2 & 2 & 41 & 3.6 \\
\hline Eritrea & 5 & 11 & 0 & 0 & & 8.0 & 8.0 & & 40 & 89 & 0 & 3.5 \\
\hline Gabon & 100 & 100 & 62 & 62 & & 2.0 & 2.0 & & (.) & (.) & 25 & 3.5 \\
\hline Ghana $^{5,6}$ & 83 & 80 & 89 & 88 & 96 & 11.7 & 4.3 & 13.1 & 17 & 19 & 99 & 5.0 \\
\hline Kenya $^{5,6}$ & 98 & 22 & 93 & 5 & 94 & 15.7 & 10.2 & 16.8 & 2 & 72 & 76 & 4.8 \\
\hline Mauritius $^{5}$ & 97 & 1 & 50 & 0 & 50 & 13.9 & 7.7 & 14.1 & 3 & 98 & 82 & 4.5 \\
\hline Namibia $^{5,6}$ & 74 & (.) & 77 & 84 & 77 & 16.5 & 6.0 & 17.3 & 26 & 100 & 99 & 4.0 \\
\hline Nigeria & 100 & 100 & 96 & 96 & & 6.5 & 6.5 & & (.) & (.) & 73 & 4.0 \\
\hline Senegal ${ }^{5,6}$ & 4 & 2 & 17 & 42 & 0 & 10.5 & 11.4 & 9.9 & 90 & 93 & 83 & 3.1 \\
\hline Seychelles & 98 & 100 & 0 & 0 & & 1.5 & 1.5 & & (.) & (.) & 15 & 3.2 \\
\hline South Africa ${ }^{5}$ & 56 & 49 & 86 & 95 & 54 & 11.5 & 6.3 & 15.5 & 40 & 46 & 93 & 3.8 \\
\hline Swaziland $^{5}$ & 96 & 6 & 90 & 19 & 90 & 17.2 & 8.8 & 18.4 & 1 & 15 & 23 & 3.6 \\
\hline AGOA-LDC & & & & & & & & & & & & \\
\hline Benin & 0 & 0 & & & & & & & 0 & 0 & & \\
\hline Cape Verde ${ }^{5,6}$ & 99 & 83 & 83 & 60 & 83 & 20.7 & 22.1 & 20.4 & 2 & 74 & 18 & 17.2 \\
\hline Cen Afr Rep & 0 & 0 & & & & & & & 99 & 99 & 44 & 3.4 \\
\hline Chad & 100 & 100 & 81 & 81 & & 3.0 & 3.0 & & 100 & 100 & (.) & 2.0 \\
\hline
\end{tabular}




\begin{tabular}{|c|c|c|c|c|c|c|c|c|c|c|c|c|}
\hline & \multicolumn{2}{|c|}{ AGOA Coverage } & \multicolumn{3}{|c|}{ AGOA Utilization } & \multicolumn{3}{|c|}{ AGOA Av. Tariff Pref. } & \multicolumn{2}{|c|}{ GSP Coverage } & \multirow{2}{*}{$\begin{array}{c}\text { GSP Utilization } \\
\text { Overall } \\
\end{array}$} & \multirow{2}{*}{$\begin{array}{c}\text { GSP Av. Tariff Pref. } \\
\text { Overall } \\
\end{array}$} \\
\hline & Overall $^{4}$ & $\begin{array}{l}\text { Non- } \\
\text { App } \\
\end{array}$ & Overall $^{4}$ & $\begin{array}{l}\text { Non- } \\
\text { App }\end{array}$ & $\mathbf{A p p}^{4}$ & Overall $^{4}$ & $\begin{array}{c}\text { Non- } \\
\text { App } \\
\end{array}$ & $\mathrm{App}^{4}$ & Overall & $\begin{array}{l}\text { Non- } \\
\text { App }\end{array}$ & & \\
\hline Congo $(\mathrm{DROC})^{7}$ & 100 & 100 & 0 & 0 & & 2.1 & 2.1 & & 100 & 100 & 93 & 5.1 \\
\hline Ethiopia $^{5,6}$ & 89 & 2 & 99 & 0 & 99 & 17.8 & 4.1 & 18.3 & 11 & 99 & 97 & 3.8 \\
\hline Gambia & 0 & 0 & & & & & & & 73 & 82 & 29 & 2.5 \\
\hline Guinea & 5 & 5 & 0 & 0 & & 7.5 & 7.5 & & 97 & 99 & 21 & 3.6 \\
\hline Lesotho $^{5,6}$ & 100 & 0 & 95 & 0 & 95 & 18.4 & & 18.4 & (.) & 100 & 30 & 4.7 \\
\hline Madagascar $^{5,6}$ & 99 & 20 & 95 & 81 & 95 & 15.6 & 8.3 & 15.9 & 1 & 75 & 71 & 4.9 \\
\hline Malawi $^{5,6}$ & 100 & 10 & 97 & 100 & 97 & 18.6 & 5.3 & 19.1 & (.) & 90 & 100 & 3.2 \\
\hline Mali $^{5,6,8}$ & 25 & 13 & 0 & 1 & 0 & 11.0 & 7.2 & 13.4 & 68 & 79 & 61 & 5.0 \\
\hline Mauritania & 0 & 0 & & & & & & & 4 & 100 & 93 & 2.2 \\
\hline Mozambique $^{5,6}$ & 98 & 0 & 100 & 0 & 100 & 20.2 & & 20.2 & 2 & 78 & 39 & 3.0 \\
\hline Niger $^{5,6,8}$ & 4 & 2 & 7 & 16 & 0 & 8.2 & 8.6 & 6.7 & 79 & 81 & 12 & 4.0 \\
\hline Rwanda $^{5,6}$ & 0 & 0 & & & & & & & 98 & 98 & 4 & 4.0 \\
\hline Sao Tome/Prin. & (.) & (.) & 0 & 0 & & & & & 99 & 100 & 0 & 2.0 \\
\hline Sierra Leone & 13 & 27 & 0 & 0 & & 12.3 & 12.3 & & 35 & 73 & 9 & 3.1 \\
\hline Tanzania $^{5,6}$ & 41 & (.) & 90 & 0 & 91 & 13.8 & 5.0 & 14.7 & 16 & 27 & 90 & 4.8 \\
\hline Uganda $^{5,6}$ & 94 & 0 & 88 & 0 & 88 & 22.3 & & 22.3 & 6 & 98 & 44 & 3.7 \\
\hline Zambia ${ }^{5,6}$ & 1 & 1 & 0 & 0 & & 3.0 & 3.0 & & 97 & 97 & 100 & 5.1 \\
\hline
\end{tabular}

Ratio of eligible imports to total dutiable imports.

Ratio of imports entering under preference to total eligible imports.

${ }^{3}$ Difference between nominal ad valorem tariff equivalent and nominal preferential tariff. Covers all HS 8-digit lines with eligible US imports in 2003.

${ }^{4}$ Apparel is defined as all lines within HS 61 and 62 (including the non-US value of production-sharing (HTS 9802.00.80)). For all countries in ATPA, CBTPA and AGOA (with apparel eligibility),

overall calculations assumes all apparel is potentially eligible for apparel benefits. Thus "utilization" is actually the ratio of US imports entering under a preference to total US apparel imports.

${ }^{5}$ Country is eligible for apparel benefits.

${ }^{6}$ Country is eligible for special rule for apparel from LDC

${ }^{7}$ AGOA benefits delayed until 10/31/03.

${ }^{8}$ AGOA eligibility as of $12 / 03$.

(.) Indicates less than one percent. 


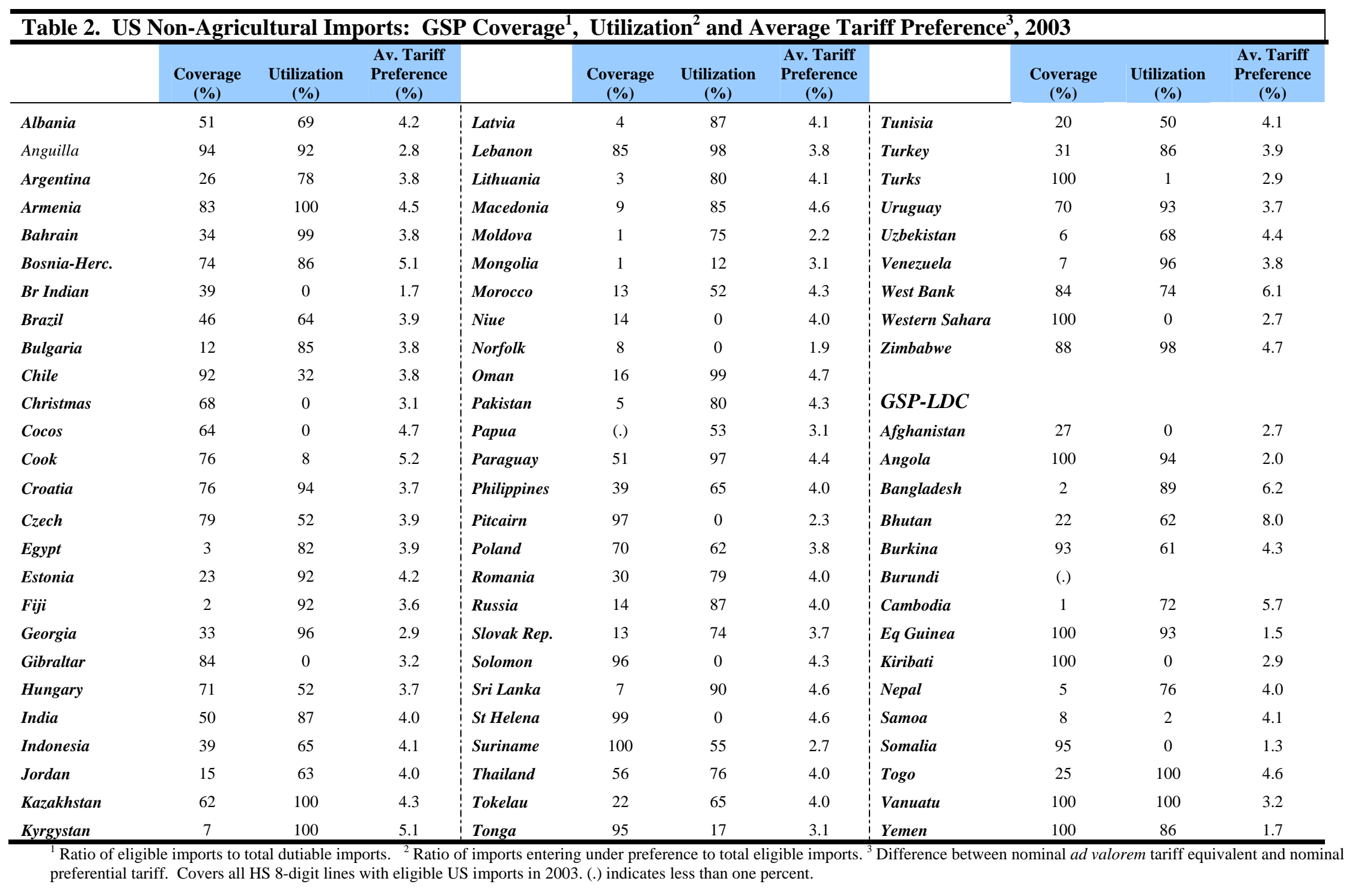




\begin{tabular}{|c|c|c|c|c|c|c|}
\hline & \multicolumn{3}{|c|}{ CBERA } & \multicolumn{3}{|c|}{ GSP } \\
\hline & Coverage (\%) & Utilization (\%) & Av. Tariff Preference (\%) & Coverage (\%) & Utilization (\%) & Av. Tariff Preference (\%) \\
\hline Antigua & 100 & 52 & 14.8 & 98 & 0 & \\
\hline \multicolumn{7}{|l|}{ Aruba } \\
\hline Bahamas & 100 & 87 & 4.1 & 0 & & \\
\hline Br Virgin Is & 100 & 100 & 3.3 & 100 & 0 & \\
\hline Dominica Is & 100 & 61 & 4.3 & 71 & 40 & 6.4 \\
\hline Grenada Is & 100 & 0 & & 100 & 0 & \\
\hline \multicolumn{7}{|l|}{ Montserrat Is } \\
\hline Netherlands Ant & 100 & 89 & 6.4 & 0 & & \\
\hline St Kitts-Nevis & 100 & 100 & 0.1 & 100 & 0 & \\
\hline \multirow[t]{3}{*}{ St Vinc / Gren } & 100 & 71 & 5.4 & 99 & 0 & \\
\hline & \multicolumn{3}{|c|}{ CBTPA } & \multicolumn{3}{|c|}{ GSP } \\
\hline & Coverage (\%) & Utilization (\%) & Av. Tariff Preference (\%) & Coverage (\%) & Utilization (\%) & Av. Tariff Preference (\%) \\
\hline Barbados & 100 & 97 & 8.3 & 82 & 0 & \\
\hline Belize & 100 & 98 & 11.0 & 60 & 3 & 3.2 \\
\hline Costa Rica & 100 & 95 & 6.4 & 40 & 11 & 6.6 \\
\hline Dominican Rep & 100 & 96 & 7.1 & 87 & 1 & 4.9 \\
\hline EI Salvador & 100 & 70 & 6.3 & 83 & 36 & 4.9 \\
\hline Guatemala & 100 & 83 & 6.3 & 79 & 17 & 5.0 \\
\hline Guyana & 100 & 87 & 4.7 & 99 & 11 & 4.8 \\
\hline Haiti & 100 & 95 & 6.3 & 100 & 4 & 4.9 \\
\hline Honduras & 100 & 82 & 7.9 & 89 & 20 & 4.5 \\
\hline Jamaica & 100 & 98 & 6.6 & 41 & 5 & 4.0 \\
\hline Nicaragua & 100 & 100 & 8.0 & 0 & & \\
\hline Panama & 100 & 94 & 7.0 & 96 & 5 & 3.6 \\
\hline St Lucia Is & 100 & 76 & 4.3 & 100 & 13 & 3.6 \\
\hline Trin \& Tobago & 100 & 93 & 9.4 & 91 & 6 & 3.5 \\
\hline
\end{tabular}




\begin{tabular}{|c|c|c|c|c|c|c|}
\hline & \multicolumn{3}{|c|}{ ATPA } & \multicolumn{3}{|c|}{ GSP } \\
\hline & Coverage (\%) & Utilization (\%) & Av. Tariff Preference (\%) & Coverage (\%) & Utilization (\%) & Av. Tariff Preference (\%) \\
\hline Bolivia & 100 & 90 & 2.6 & 92 & 7 & 2.8 \\
\hline Colombia & 100 & 90 & 6.6 & 59 & 16 & 4.6 \\
\hline Peru & 100 & 79 & 5.6 & 56 & 34 & 3.8 \\
\hline \multirow[t]{3}{*}{ Ecuador } & 100 & 91 & 6.0 & 55 & 15 & 4.8 \\
\hline & \multicolumn{3}{|c|}{ AGOA } & \multicolumn{3}{|c|}{ GSP } \\
\hline & Coverage (\%) & Utilization (\%) & Av. Tariff Preference (\%) & Coverage (\%) & Utilization (\%) & Av. Tariff Preference (\%) \\
\hline \multicolumn{7}{|l|}{ Botswana } \\
\hline Cameroon & 0 & & & 100 & 92 & 0.5 \\
\hline Congo (ROC) & 0 & & & 100 & 100 & 4.7 \\
\hline Cote d'Ivoire & (.) & 100 & 2.3 & 100 & 100 & 4.8 \\
\hline Djibouti & 0.0 & & & 100 & 100 & 1.9 \\
\hline \multicolumn{7}{|l|}{ Eritrea } \\
\hline \multicolumn{7}{|l|}{ Gabon } \\
\hline Ghana & 1 & 42 & 10.0 & 99 & 92 & 4.9 \\
\hline Kenya & 87 & 60 & 2.7 & 13 & 100 & 4.3 \\
\hline Mauritius & 0 & & & 97 & 94 & 4.9 \\
\hline Namibia & 0 & & & 100 & 100 & 3.3 \\
\hline Nigeria & 1 & 0 & & 99 & 84 & 3.3 \\
\hline Senegal & 17 & 100 & 8.2 & 83 & 100 & 6.6 \\
\hline \multicolumn{7}{|l|}{ Seychelles } \\
\hline South Africa & 80 & 88 & 9.5 & 16 & 96 & 4.2 \\
\hline Swaziland & 10 & 77 & 21.9 & 89 & 100 & 3.4 \\
\hline \multicolumn{7}{|l|}{ AGOA-LDC } \\
\hline Benin & 100 & 0 & & 100 & 0 & \\
\hline \multicolumn{7}{|l|}{ Cape Verde } \\
\hline Cen Afr Rep & & & & & & \\
\hline
\end{tabular}




\begin{tabular}{|c|c|c|c|c|c|c|}
\hline & & AGOA & & & GSP & \\
\hline & Coverage (\%) & Utilization (\%) & Av. Tariff Preference (\%) & Coverage (\%) & Utilization (\%) & Av. Tariff Preference (\%) \\
\hline \multicolumn{7}{|l|}{ Chad } \\
\hline Congo $(D R O C)^{4}$ & 0 & & & 100 & 100 & 1.0 \\
\hline Ethiopia & 39 & 6 & 1.3 & 100 & 92 & 3.1 \\
\hline \multicolumn{7}{|l|}{ Gambia } \\
\hline Guinea & 0 & & & 100 & 100 & 6.1 \\
\hline \multicolumn{7}{|l|}{ Lesotho } \\
\hline Madagascar & 0 & & & 100 & 71 & 3.7 \\
\hline Malawi & 92 & 30 & 9.2 & 100 & 49 & 6.3 \\
\hline \multicolumn{7}{|l|}{ Mali $^{5}$} \\
\hline \multicolumn{7}{|l|}{ Mauritania } \\
\hline Mozambique & 0 & & & 100 & 100 & 3.4 \\
\hline \multicolumn{7}{|l|}{ Rwanda } \\
\hline \multicolumn{7}{|l|}{ Sao Tome/Prin. } \\
\hline Sierra Leone & 60 & 0 & & 100 & 33 & 11.3 \\
\hline Tanzania & 59 & 94 & 6.8 & 41 & 67 & 2.8 \\
\hline Uganda & 42 & 68 & 2.3 & 100 & 72 & 0.7 \\
\hline Zambia & 41 & 0 & & 100 & 59 & 5.8 \\
\hline $\begin{array}{l}\text { Ratio of eligible im } \\
\text { Ratio of imports en } \\
\text { Difference between } \\
\text { AGOA benefits del } \\
\text { AGOA eligibility a } \\
\text {.) Indicates less than }\end{array}$ & $\begin{array}{l}\text { total dutiable imp } \\
\text { nder preference to } \\
\text { al ad valorem tari } \\
\text { til 10/31/03. } \\
\text { o3. } \\
\text { rcent. }\end{array}$ & $\begin{array}{l}\text { ligible imports. } \\
\text { alent and nomina }\end{array}$ & arential tariff. Covers all HS 8 & t lines with eligil & imports in 2003. & \\
\hline
\end{tabular}




\begin{tabular}{|c|c|c|c|c|c|c|c|c|c|c|c|}
\hline GSP & $\begin{array}{c}\text { Coverage } \\
(\%)\end{array}$ & $\begin{array}{c}\text { Utilization } \\
(\%)\end{array}$ & $\begin{array}{c}\text { Av. Tariff } \\
\text { Preference } \\
(\%)\end{array}$ & & $\begin{array}{c}\text { Coverage } \\
(\%)\end{array}$ & $\begin{array}{c}\text { Utilization } \\
(\%)\end{array}$ & $\begin{array}{c}\text { Av. Tariff } \\
\text { Preference } \\
(\%)\end{array}$ & & $\begin{array}{c}\text { Coverage } \\
(\%)\end{array}$ & Utilization (\%) & $\begin{array}{c}\text { Av. Tariff } \\
\text { Preference } \\
(\%) \\
\end{array}$ \\
\hline Albania & 100 & 34 & 1.9 & Kyrgystan & & & & Tonga & 98 & 100 & 7.0 \\
\hline Anguilla & 100 & 100 & 6.0 & Latvia & 6 & 98 & 4.2 & Tunisia & 94 & 98 & 4.2 \\
\hline Argentina & 36 & 87 & 4.5 & Lebanon & 89 & 97 & 4.6 & Turkey & 43 & 97 & 4.3 \\
\hline Armenia & 57 & 98 & 5.5 & Lithuania & 2 & 83 & 5.4 & Turks and Caicos Is. & & & \\
\hline Bahrain & & & & Macedonia & 76 & 97 & 6.6 & Uruguay & 11 & 94 & 5.3 \\
\hline Bosnia-Hercegov. & 90 & 85 & 5.8 & Moldova & 30 & 71 & 6.6 & Uzbekistan & 100 & 100 & 3.8 \\
\hline Br Indian & & & & Mongolia & 0 & & & Venezuela & 95 & 99 & 3.7 \\
\hline Brazil & 24 & 95 & 4.0 & Morocco & 49 & 41 & 6.8 & West Bank & 100 & 100 & 1.3 \\
\hline Bulgaria & 68 & 97 & 4.3 & Niue & & & & Western Sahara & & & \\
\hline Chile & 14 & 83 & 3.8 & Norfolk & 100 & 57 & 2.4 & Zimbabwe & & & \\
\hline Christmas & & & & Oman & 20 & 92 & 1.4 & GSP-LDC & & & \\
\hline Cocos Is. & & & & Pakistan & 49 & 99 & 4.2 & Afghanistan & 1 & 0 & \\
\hline Cook & 0 & & & Рариа & 100 & 100 & 3.4 & Angola & & & \\
\hline Croatia & 87 & 99 & 4.6 & Paraguay & 68 & 100 & 3.7 & Bangladesh & 100 & 68 & 5.9 \\
\hline Czech & 88 & 81 & 6.2 & Philippines & 41 & 86 & 4.9 & Bhutan & 100 & 100 & 3.0 \\
\hline Egypt & 28 & 98 & 4.2 & Pitcairn & 100 & 100 & 5.6 & Burkina & 100 & 62 & 3.7 \\
\hline Estonia & 99 & 97 & 3.7 & Poland & 88 & 69 & 5.3 & Burundi & & & \\
\hline Fiji & 98 & 100 & 3.9 & Romania & 14 & 63 & 4.3 & Cambodia & 100 & 88 & 10.6 \\
\hline Georgia & 23 & 82 & 4.6 & Russia & 84 & 95 & 3.5 & Eq Guinea & & & \\
\hline Gibraltar & & & & Slovak Rep. & 24 & 84 & 4.5 & Kiribati & & & \\
\hline Heard/McDonald & 100 & 100 & 7.0 & Solomon Is. & & & & Nepal & 100 & 92 & 5.0 \\
\hline Hungary & 71 & 68 & 4.2 & Sri Lanka & 93 & 94 & 3.8 & Samoa & 100 & 23 & 4.0 \\
\hline India & 40 & 95 & 4.2 & St Helena & & & & Somalia & 100 & 0 & \\
\hline Indonesia & 37 & 97 & 4.4 & Suriname & 100 & 100 & 1.8 & Togo & 69 & 100 & 8.3 \\
\hline Jordan & 84 & 76 & 5.3 & Thailand & 39 & 96 & 4.9 & Vanuatu & 100 & 0 & \\
\hline Kazakhstan & 0 & & & Tokelau & 100 & 0 & & Yemen & & & \\
\hline
\end{tabular}

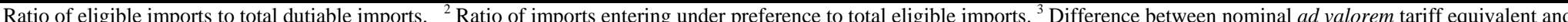
nominal preferential tariff. Covers all HS 8-digit lines with eligible US imports in 2003. (.) indicates less than one percent. 


\begin{tabular}{|c|c|c|c|c|c|c|c|c|}
\hline & \multicolumn{4}{|c|}{ Assuming Full Utilization } & \multicolumn{4}{|c|}{ Incorporating Actual Utilization } \\
\hline & & Value & Non-Ag & Ag & \multirow{2}{*}{$\begin{array}{c}\text { Value } \\
\text { (\% of Total } \\
\text { Exports to US) } \\
\end{array}$} & Value & Non-Ag & Ag \\
\hline Beneficiaries of: & $\begin{array}{c}\text { (\% of Total } \\
\text { Exports to US) }\end{array}$ & \multicolumn{3}{|c|}{ (\% of Dutiable Exports to US) } & & \multicolumn{3}{|c|}{ (\% of Dutiable Exports to US) } \\
\hline \multicolumn{9}{|l|}{ All Preference Programs } \\
\hline All Beneficiaries & 2.0 & 3.0 & 2.8 & 0.2 & 1.5 & 2.3 & 2.1 & 0.2 \\
\hline All LDC Beneficiaries & 2.0 & 2.2 & 2.1 & 0.1 & 1.8 & 1.9 & 1.9 & 0.0 \\
\hline \multicolumn{9}{|l|}{ CBERA-only \& GSP } \\
\hline All beneficiaries & 0.4 & 0.5 & 0.5 & 0.0 & 0.4 & 0.4 & 0.4 & 0.0 \\
\hline St Vincent \&Gren. & 4.4 & 5.3 & 5.2 & 0.1 & 4.3 & 5.3 & 5.2 & 0.1 \\
\hline Dominica Is & 3.5 & 5.3 & 4.4 & 1.0 & 3.4 & 5.2 & 4.3 & 0.9 \\
\hline Antigua Barbuda & 1.0 & 5.1 & 4.4 & 0.7 & 0.2 & 0.8 & 0.1 & 0.6 \\
\hline \multicolumn{9}{|l|}{ CBTPA \& GSP } \\
\hline All beneficiaries & 8.7 & 12.7 & 12.0 & 0.7 & 6.0 & 8.8 & 8.0 & 0.7 \\
\hline Haiti & 17.3 & 18.1 & 18.0 & 0.1 & 12.3 & 12.9 & 12.8 & 0.1 \\
\hline Belize & 8.2 & 17.5 & 4.8 & 12.7 & 7.8 & 16.5 & 3.8 & 12.7 \\
\hline El Salvador & 15.3 & 16.1 & 16.0 & 0.1 & 10.1 & 10.7 & 10.5 & 0.1 \\
\hline Honduras & 14.2 & 16.1 & 15.7 & 0.4 & 11.2 & 12.7 & 12.2 & 0.4 \\
\hline Guatemala & 12.4 & 15.6 & 14.3 & 1.3 & 5.1 & 6.4 & 5.1 & 1.3 \\
\hline Nicaragua & 11.9 & 14.6 & 14.2 & 0.4 & 4.7 & 5.7 & 5.3 & 0.4 \\
\hline Guyana & 2.5 & 12.5 & 11.2 & 1.4 & 2.2 & 11.3 & 10.0 & 1.3 \\
\hline Dominican Rep & 9.8 & 12.2 & 11.8 & 0.4 & 7.9 & 9.9 & 9.5 & 0.4 \\
\hline Costa Rica & 4.2 & 9.9 & 7.1 & 2.9 & 3.5 & 8.2 & 5.4 & 2.9 \\
\hline Jamaica & 3.1 & 9.9 & 8.3 & 1.7 & 4.5 & 8.8 & 7.1 & 1.6 \\
\hline St Lucia Is & 5.2 & 6.8 & 6.7 & 0.1 & 1.2 & 1.6 & 1.5 & 0.1 \\
\hline Barbados & 2.6 & 5.6 & 1.1 & 4.5 & 2.4 & 5.1 & 0.6 & 4.5 \\
\hline \multicolumn{9}{|l|}{ ATPA \& GSP } \\
\hline All beneficiaries & 2.7 & 3.8 & 3.0 & 0.8 & 2.2 & 3.1 & 2.3 & 0.8 \\
\hline Bolivia & 5.5 & 7.9 & 7.8 & 0.1 & 5.2 & 7.5 & 7.4 & 0.1 \\
\hline Peru & 5.2 & 6.2 & 5.3 & 0.9 & 4.8 & 5.7 & 4.8 & 0.9 \\
\hline
\end{tabular}




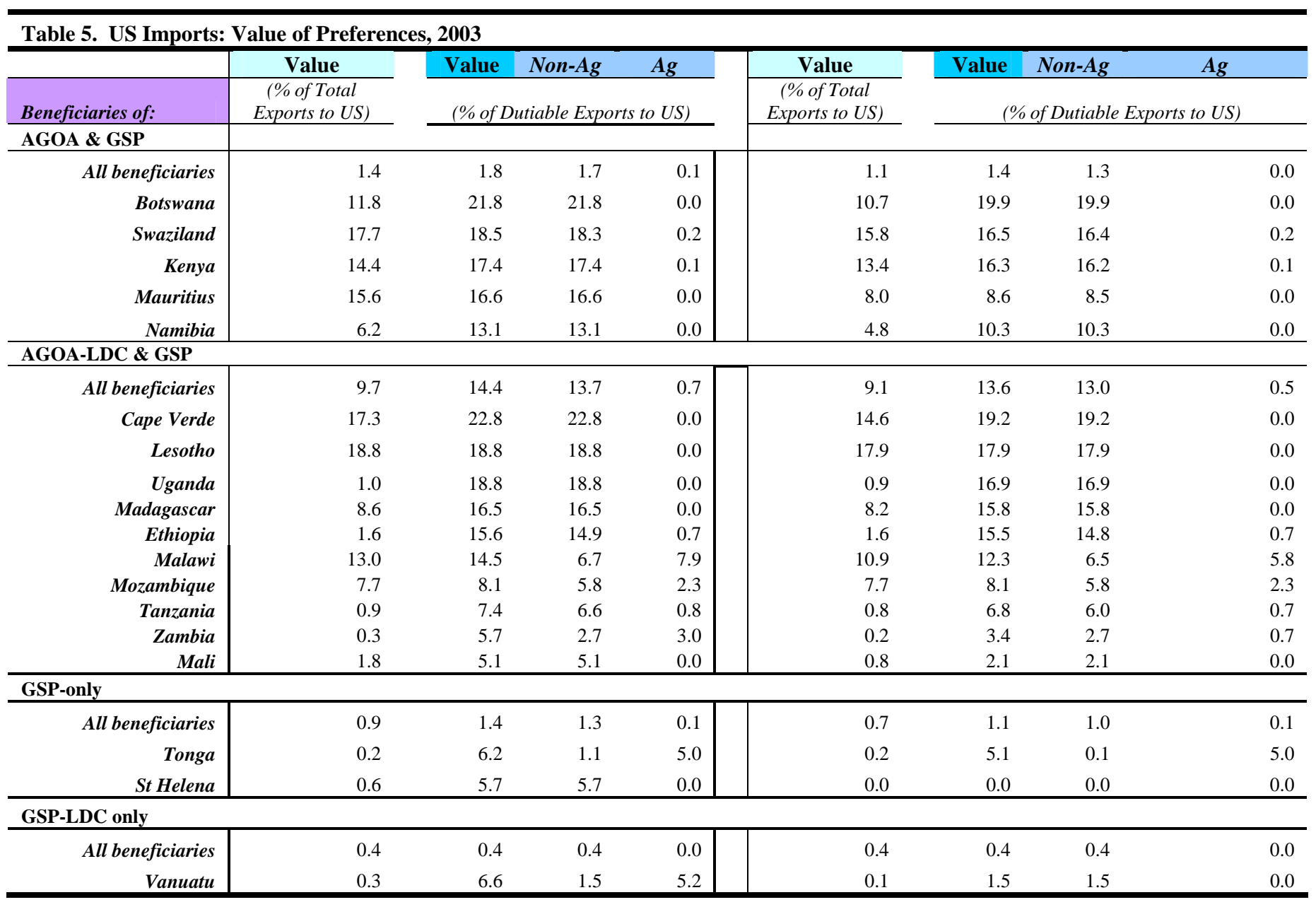


Table 6. US Non-Agricultural Imports: Value of Preferences, 2003

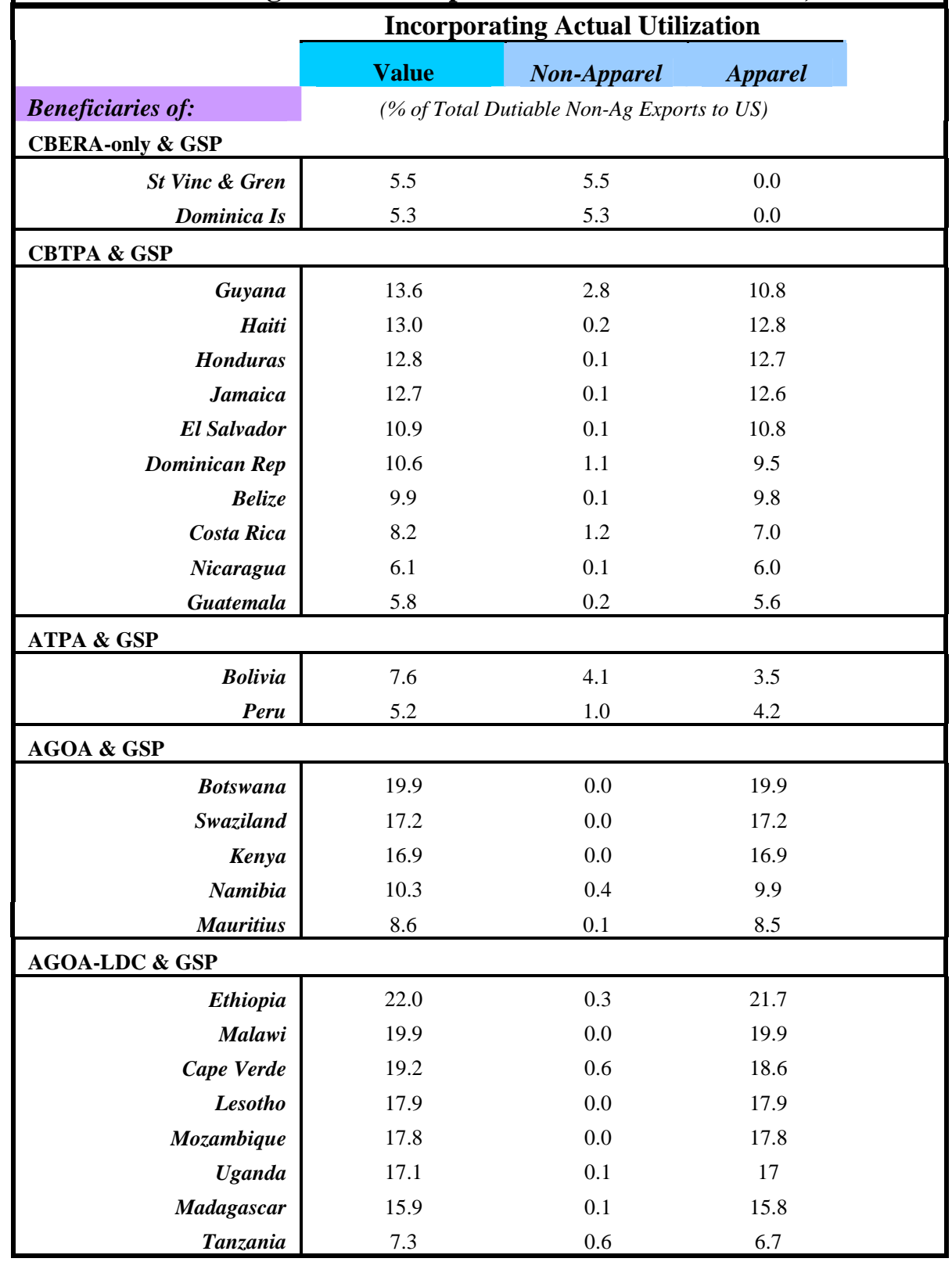




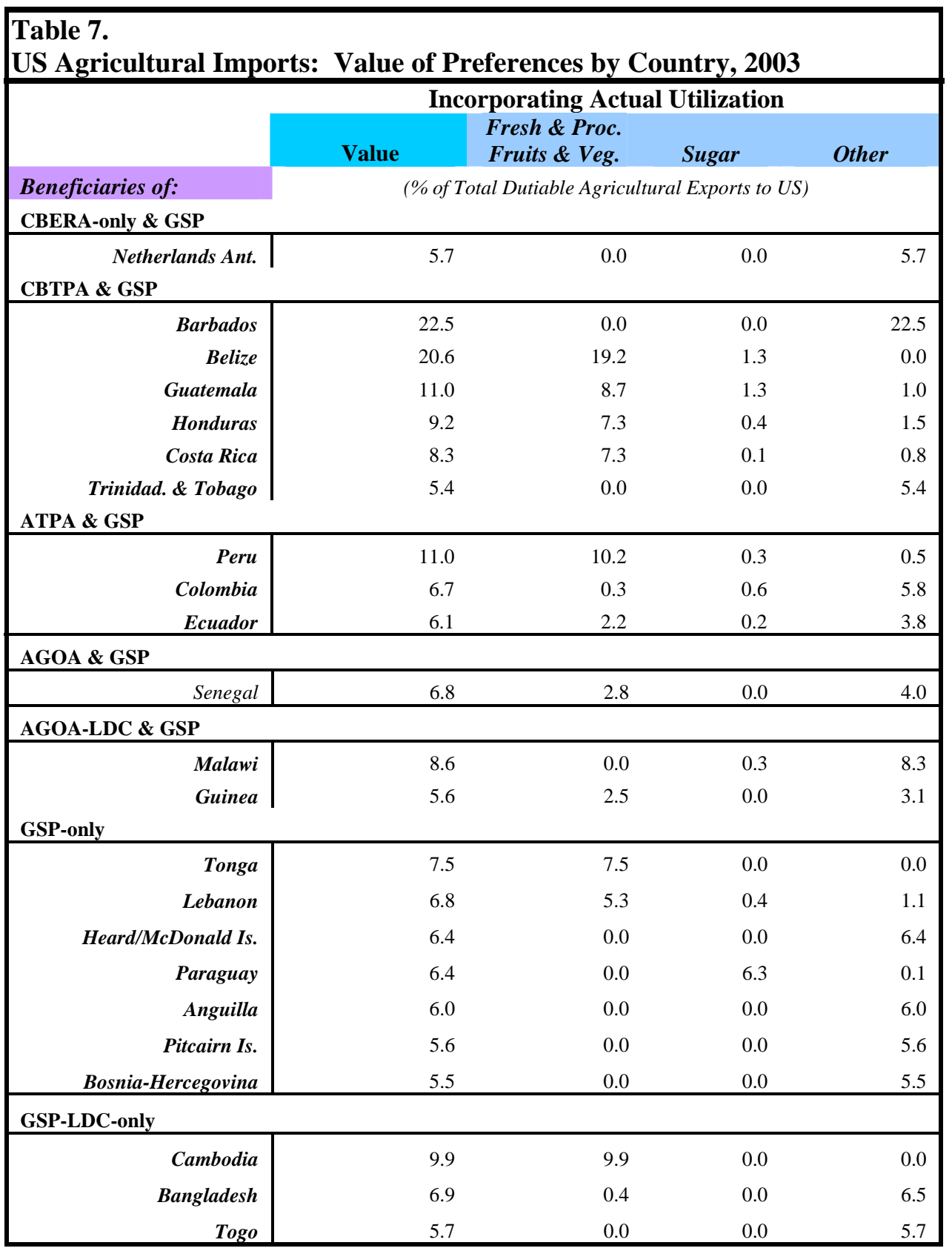

